EP-93

\title{
Biological activity of ascaridole for the treatment of cancers: Phytopharmaceutical importance with molecular study
}

\author{
Kanika PATEL, Dinesh Kumar PATEL*
}

Faculty of Health Sciences, Sam Higginbottom University of Agriculture, Technology and Sciences, Prayagraj, India

Introduction: Cancers are the leading cause of Human death worldwide and anything which can cause a normal body cell to abnormal cell can produce various forms of cancers. Ascaridole have been used in the medicine for the treatment of ascarids and hookworms and in the modern medicine it has been also used for the treatment of numeraous health complications.

Methods: Due to toxic effect of ascaridole, present investigation deals the study of ascaridole for their anticancer activity through literature data analysis of different scientific research. Further to understand their anti-cancer activity in better way, molecular study of ascaridole has been also investigated through literature data analysis of topoisomerase I, epidermal growth factor and tubulin. All the presented data have been thoroughly analyzed to know the therapeutic potential of ascaridole for the treatment of cancerous disorders. Results: Literature data analysis of the different scientific sources revealed the medicinal importance of ascaridole for the effectiveness against various form of cancers. Literature data analysis of scientific work of research field revealed antineoplastic and antitumor activity of ascaridole in sarcoma 180 murine model, different tumor cell lines such as CCRF-CEM, HL60 and MDA-MB-231. Molecular study data analysis also revealed the importance of binding sites of topoisomerase I, topoisomerase II, epidermal growth factor receptor and tubulin in the treatment of various form of cancers. Literature data analysis revealed better medicinal importance and pharmacological activity against cancerous disorders.

Conclusions: Literature data analysis study in the present work revealed the biological importance of ascaridole in the medicinal filed and it could be also beneficial in the field of medicine. 